\title{
Latîfe ez-Zeyyât'ın El-Bâbu'l-Meftûh (Açık Kapı) Adlı Romanında Kadın Teması Üzerinden Ulusal ve Bireysel Özgürlüğün İnşâsı
}

\author{
Doç. Dr. Asiye Çelenlioğlu \\ Fatih Sultan Mehmet Vakıf Üniversitesi, Eğitim Fakültesi \\ Yabancı Diller Ĕ̆itimi Bölümü \\ acelenlioglu@fsm.edu.tr
}

Öz

Batı'da görünürlügüüü yitirdikten sonra Doğu'da gündem olmaya devam eden kadın hak ve özgürlükleriyle ilgili sorunlar, hâkim ideoloji tarafından Şark'a_mahsus olarak lanse edildiği gibi otoriter rejimlerdeki demokrasi sorunundan beslendiği de göz ardı edilmiştir. Söz konusu bölgede kadın ve vatan olgusu, "namus" temelli bakış açısıyla ulusal tarih yazımında başat rol oynarken Mısır'da kadının ulusal direnişten beslenen özgürlük arayışı, zamanla bireysel bir tavra evrilir. Ülkede kadın hareketiyle ilgili tarihi akış yanında edebî literatür de bu yönde bir birikime sahiptir. Bölge ülkeleri arasında Batı ile teması en erken gerçekleşen Mısır'da, o dönem meydana gelen yeni fikir akımlarından beslenen ilk Mısır romanı Zeynep'e konu olan kadın olgusu, direniş romanları başta olmak üzere edebi literatürde yer almaya devam etmiştir. Latîfe ez-Zeyyât'ın kronolojik olarak Hür Subaylar Darbesinden hemen önce başlayıp on yıllık dilimde Mısır siyasi tarihindeki gelişmelere değindiği Açık Kapı (el-Bâbu'l-Meftûh, 1960) romanında bu mücadele oldukça barizdir. Roman; kadının toplumsal alanda milli direnişten beslenen görünürlüğü, özgürlüğü önündeki gelenek, norm gibi engellerle mücadelesi ve benlik arayışını konu edinmektedir. Söz konusu çalışma gündelik hayatın sıradan eylemleriyle normları esneterek kimliğini inşa eden kadının öznel tavrını genel kavramlarla açıklamayı hedeflemektedir.

Anahtar Kelimeler: Mısır, Edebiyat, Roman, Kadın, Latîfe ez-Zeyyât.

\section{The Construction of National and Individual Freedom Through on the Theme of Women in Latîfe ez-Zeyyât's Novel, El-Bâbu'l-Meftûh (The Open Door)}

\section{Abstract}

The problems regarding women's rights and freedoms, which remained on the agenda in the East after losing their visibility in the West, were ignored by the dominant ideology, as well as being fed by the problem of democracy in authoritarian regimes. While the phenomenon of women and homeland in this region plays a dominant role in national historiography from an honor-based perspective, women's pursuit of freedom, nurtured by national resistance, evolved over time in an individual manner. This struggle is obvious in the novel Open Door, in which ez-Zeyyât began chronologically just before the Coup of Independent Officers and touched on the developments in Egyptian political history in ten 
years. The novel focuses on the visibility of national women, which is fed by national resistance, the struggle against freedom such as tradition, norm and the search for self. This study aims to explain the subjective attitude of the woman who builds her identity by stretching the norms with the ordinary actions of everyday life with general concepts.

Keywords: Egypt, Literature, Novel, Woman, Latife Zeyyat. 


\section{GİRIŞ}

Toplumsal yapıyı besleyen ana damarlardan din, tarih, mitos gibi olgularla şekillenen değer ve normlar; nesilden nesle aktarılırken gündelik hayatın sıradan olaylarıyla esneyip değişebilmektedir. Olumlu ya da olumsuz olarak bireyin tercihi yönünde meydana gelen bu değişimin hareket noktası onun iç görüsüdür. Arzu ve istekleriyle çelişen değer ve normlara karşı takındığı durum direnişi ölçüsünde değişime kapı aralarken ödemeye hazır olduğu bedel de değişimin gücünü pekiştirmektedir.

Batı'da görünürlüğünü kaybettikten sonra Doğu'da gündem olmaya devam eden kadın hak ve özgürlükleriyle ilgili sorunlar, hâkim ideoloji tarafından Şark'a mahsus sorunlar olarak lanse edildiği gibi otoriter rejimlerdeki demokrasi sorunundan beslendiği de göz ardı edilmiştir.

Orta Doğu ülkeleri arasında Batıyla teması en erken gerçekleşen Mısır'da o dönem meydana gelen yeni fikir akımlarından biri de kadının özgürlüğü konusudur. Kâsım Emîn toplumsal hayatta kadının daha çok yer almasını ve onları gelecek nesillerin kültürlü anneleri haline getirecek reformların yapılmasını savunmuştur. ${ }^{1} \mathrm{Bu}$ düşünceler modern Mısır romanının doğuşunda etkili olmuş; ilk roman özelliği taşıyan Zeynep (1914) adlı eser, bu görüşlerin savunucularından Muhammed Hüseyin Heykel tarafından yazılmıştır.

Geniş halk kitleleri tarafından desteklenen VEFD Partisi Kadın Komitesi lideri Hüdâ Şârâvî tarafından 1924 yılında Mısır Feminist Birliği kurulmuş, bu hareketin çıkış noktası Batılı değerleri referans almak olmuştur. Hüdâ Şârâvî'nin Roma'da gerçekleşen uluslararası bir feminist konferansa katılımı sonrası, Sîza Nabrâvî ve Nebeviye Musa ile birlikte peçesini çıkartarak denize atması, oluşuma damga vuran olaylar arasındadır (el-Berâzî, 2016, s. 1128).

Mısır'da siyasi oluşumların toplumsal alanla ilgili reçeteleri, referans aldıkları ideolojinin bakış açısıyla şekillenirken Cemâleddîn Afgânî (1838-1897)-Muhammed Abduh (1849-1905) çizgisinde seyreden dinî çözüm önerileri, Lebîbe Ahmed (1870-1951) (Bora, 2010, s. 53) ve Zeynep el-Gazali'nin (1917-2005) (Lewis, 2007, s. 12) söylemlerinde İslami feminizm kisvesine bürünmüştür. Ataerkil ulema tarafından yorumlanan kadınlarla ilgili ayet metinlerinde yer alan kelimelerin diğer anlamalarının da göz önüne alınarak yeniden yorumlanması tezini savunan görüşün ardında, İslamın ilk kaynağına dönme fikri yatmaktadır. Sahabe kadını imajını ön plana çıkaran bu söylem 1919'da İngiltere'ye karşı bağımsızlığın kazanılmasında büyük rol oynayan VEFD'in direnişinde kadınların kendine yer bulmasına neden olmuştur.

Batı'nın menfaati gereği destek verdiği otoriter rejimlerin Doğu'da_kadını hapsettiği alan, tarihi ve dini zeminin kadına çizdiği sınırlardan daha dardır. Hâlbuki gerek erken dönem tarihinde tanrıçaların konumu gerekse İslamî referanslarda kadınla ilgili malumat nedeniyle Mısır, feminist direnişe başarı kazandıracak alt yapıya sahiptir. (Kandiyoti, 1997).

Mısır'da Türkiye'yle hemen hemen aynı dönemde başlayan kadın hareketinin o dönemde evlilik yaşında sağlanan iyileştirme dışında hukuksal bir kazanım elde edememiş

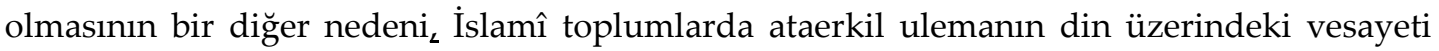
olmuştur. Kader inancı başta olmak üzere dinî ve siyasî_otoriteyi sorgulanmaz bir konuma

${ }^{1}$ Kâsım Emîn bu çağrıyı 1899 yılında yayımladığı Taḥ̂îru'l-mer'e (Kadının Özgürleştirilmesi) ve 1900'de yayımladığı el-Mer'etu-l-cedîde (Modern Kadın) adlı eserlerle yapmiştır. 
yerleştiren itaat anlayışı gibi özgürlük ve ilerlemenin önündeki engeller aynı toplumsal yapının bir parçası olan kadının bireysel kazanımlarıyla ilgili de engel teşkil etmiştir.

\section{MODERN MISIR EDEBIYYATINDA KADIN OLGUSU}

Bir toplumdaki üyelerin ortak davranışlarını belirleyen normatif değerler sosyalleşme süreci içinde öğrenilir ve nesilden nesile aktarılır. Değer, yargı, inanç, simge ve davranış ölçütleri belli bir toplumda onu diğerlerinden ayıran ortak özellikler gösterse de alt guruplar arasında farklılaşmış kültür öğelerine rastlamak mümkündür. Türk milletinin genel kültür özellikleri yanında Karadeniz insanının yöresel özellikler göstermesi şeklinde açılanacak bu durum, sosyo ekonomik duruma göre kümelenen guruplar arasında farklılıklar göstermektedir. Kültür; değişen ihtiyaçların, yeni bireysel, grupsal ya da toplumsal deneyimlerin, ancak yeni kuşakların anlayabileceği zorunlulukların toplumun yapısını etkilediği yön ve düzeyde farklılaşan dinamik bir yapıya sahiptir (Tolan, 1996, s. 228). İşte tam da bu sebeplerle toplumu; kurguladıkları hikâyelerde yansıtan, eleştirip yorumlayan aynı ırka ait romanlarda, aynı olgunun farklı yönlerini görmek mümkündür.

Açık Kapı romanında "Leyla” 1950'li yıllarda Kahire'de ataerkil bir ailede, gündelik hayatın alışıla gelmiş davranışlarıyla norm ve gelenekleri aşındırmaya çalışırken, ulusal direnişin zafer-yenilgi çizgisiyle uyumlu direnç ve vazgeçiş arasında gidip gelmektedir. Hâlbuki aynı yıllarda Şarkâvî'nin Fellâh (Çiftçi 1967) romanında köy kadınları devrim sonrası gerçekleşen reformlarda yer alma ve eş seçimi gibi bireysel haklarını elde etme konusunda çok başarılıdır. Aynı yazarın Sıdkî iktidarının köylüde yarattığı yıkımı konu edindiği el-Ard (Toprak; 1954), 1935 yılı sokak direnişlerini konu edindiği Eş-Şevâriu'lHalfiyye (Arka Sokaklar; 1958) ve II. Dünya Savaşı'nda İngiltere'nin vesayeti altındaki ülkede yaşanan sosyo ekonomik sıkıntıyı ele aldığı Kulûb Hâliye (Boş Kalpler;1956) romanlarında kadın karakterler kendine güvenen, mücadeleci ve gelenekleri yıpratacak şekilde karakterize edilmiştir.

Necip Mahfuz'un Üçleme adıyla meşhur 1917-1944 yılları arasını konu edindiği romanlarda ${ }^{2}$ kadının üç kuşakta elde ettiği kazanımları görmek mümkündür. İlk kuşak kadınları kocasına sonsuz itaatle yükümlüyken, ikinci kuşak kadınlar evliliklerinde daha özgür ve evlerinde söz sahibi olmuştur. Üçüncü kuşakta ise kadınların artık iş hayatında yer almaya başladığı görülür.

Mısır'ın yerel yönetime kavuştuğu 1952 yılı öncesi İngiltere'nin sömürgesi ya da yarı sömürgesi olduğu dönemde Kahire başta olmak üzere büyük şehirlerde meydana gelen yozlaşmanın etkilerini, kadın başta olmak üzere toplumsal alanda görmek mümkündür. Türkiye Batılılaşmasına benzer şekilde, Mısır'da elit kesim arasında başlayan modern hayatın öznesi olan kadınlar yanında, fakirlik nedeniyle nesnesi durumuna gelenler de mevcuttur. Romanlarda yozlaşma ya da fakirlik başlığı altında eleştirilen bu durum kadını sosyal zeminde tasvir etmektedir.

Açık Kapı romanının kadını değişik kompozisyonlarda işleyen diğer romanlardan farkı; onu merkeze alarak toplum içinde benlik arayışına, arzularıyla gelenekler arasındaki çatışmaya, normları esnetme mücadelesine odaklanmasıdır. Asıl ve üsul arasındaki doğrunun sorgulandığı romanda normlarla bastırılan duyguların neden olduğu sapmalara da işaret edilmiştir.

2 Beyne'l-Kasrayn (1956), Kasru'ş-Şevk (1957), es-Sukkeriye (1957) adlı üç romandan meydana gelen üçlemesidir. 


\section{AÇIK KAPI (el-BÂBU'L-MEFTÛH, 1960) ROMANI}

Latîfe ez-Zeyyât ${ }^{3}$, romanına 1946 yılını not düşerek başlar. Bu tarih; II. Dünya Savaşından sonra İngiltere'yle ilişkilerin 1936 anlaşması çerçevesinde devam ettiği Mısır'da kral, derebeylik ve sömürge üçgeninde yaşanan sıkıntılara tepki olarak gerçekleşen halk eylemlerinden birinin tarihidir. Romanda ana temayı oluşturan Leyla'nın benlik kazanımı, ülkenin siyasi kazanımlarıyla paralel seyrettiği için bu ana temaya vurgu mahiyetindedir.

1960 yılında okuyucuyla buluşan, arka fonda siyasetin yer aldığ romanda yazar; kadın, aile ve gelenekler üzerinden bireyin ve ülkenin özgürlüğüne odaklanılmıştır. Otuz bölüm ve 464 sayfadan oluşan romanın konuşma cümleleri Mısır lehçesiyle kaleme alınmıştır.

\subsection{Romanda Siyasî Arka Plan}

Mısır'da kadının toplumsal alanda varlığı, ulusal direnişle başladığı (Kemal, 2016, s. 10-11) ve ülkede görünürlüğü, 1952 Hür Subaylar Devrimi'nden sonra gerçekleşen reformlarla arttığı için; söz konusu romanda bilinçli olarak kullanılan siyasi arka fon, genel olarak Mısır romanının karakteristik özellikleri arasındadır. Günlük yaşantıyı tarihi olaylarla ilişkilendirmek, siyasi başarıları eğlence nedeni kabul etmek, birlik ve beraberliği ulusal direniş etrafında perçinlemek, kahramanları siyasetle ilintili yaratmak Mısır romanının neredeyse olmazsa olmazıdır.

Söz konusu romanda 1946 yılıyla başlayan siyasi akış 1957 yılına kadar ülke tarihine damgasını vuran olaylarla devam etmiş, her kazanım gibi her kayıp Leyla'nın ruhunda yankı bulmuştur. Romanda yer alan siyasi başlıklar aşağıdaki gibidir.

\subsection{1. İngiliz Sömürgeciliği}

Ülkede Urâbî Paşa İsyanıyla_başlayan İngiliz sömürgeciliği fiilen 1956 yılına kadar sürmüş, 1919, 1936, 1952 devrimleriyle elde edilen kazanımlara rağmen otoriter rejimlerin baskıcı tutumuna karşı direniş devam edegelmiştir. Ortadoğu'da oryantalist söylemlerin aksine halkın demokrasi arayışı iç ve diş dinamiklerin (Demirtaş, 2017) yarattığı çerçeveye hapsolurken bu söylemlerdeki yanılgıyı Mısır romanı dile getirmeye devam etmiştir.

1919 yllında VEFD Partisi lideri Sa'd Zağlûl'un önderliğindeki girişimlerle 1922 yılında elde edilen kısmi özgürlük, İngiltere'nin Süveyş Kanalındaki askerî_varlığı dışında ülke güvenliğini yerel yöneticilere bırakmasıyla 1936 yılında bir adım öteye taşınır. Ancak İngiltere'nin 1939 yılında II. Dünya Savaşı'na girmesiyle savaş üssü haline gelen Mısır'da toplumsal ve ekonomik şartların tamamen alt üst olması halkın huzursuzluğunu arttırmış; savaş sonrası diğer kazanımlarını elde ederken olduğu gibi halk, yine sokaktaki yerini almiştır.

\footnotetext{
${ }^{3}$ Latîfe ez-Zeyyât 8 Ağustos 1923 tarihinde Dimyât'ta doğmuştur. Kahire Üniversitesi İngiliz Dili ve Edebiyatı bölümünden 1946 yılında mezun olmuş 1957 yılında aynı üniversitede doktorasını tamamlamıştır. 12 yaşına kadar babasının belediye meclisindeki görevi nedeniyle pek çok şehir dolaşmış onun ölümünden sonra 1946 yılına kadar Kahire'de ikamet etmiştir. 1952 yılında ders vermeye başladığı Ayn Şems Üniversitesi Kız Fakültesi'nde kadın sorunları ve toplumla ilişkisine dair farkındalık kazanır. Öğrenciliğinden itibaren Marksist eğilimde olan Latîfe ezZeyyât 1965 yılından 1968 yılına kadar haftalık olarak Heva' dergisinde kadın sorunlarıyla ilgili yazılar kaleme alır. 1940'lı yıllarda öğrenci hareketlerine katılmış, 1946 yılında İngilizlere karşı Mısır Halk Mücadelesi'ni savunan Ulusal Öğrenci Komitesi'nin sekreterliğini yapmıştır. İki kez evlenen Latîfe ez-Zeyyât 1996 yılında vefat etmiştir. Diğer edebi eserleri: eş-Şeyhhûha ve Kısas Uhrâ (Yaşlılık ve Diğer Hikâyeler, 1996), Er-Raculü'l-Lezî Arefe Töhmetehu (Suçunu Bilen Adam, 1986), Hamletu Teftîş: Evrâk Şahsiyye (Denetim Kampanyası: Şahsi Belgeler, 1992), Bey ve Şirâ (Alışveriş; 1994), Sâhibu'l-Beyt (Ev Sahibi, 1994).
} 
Roman, İngiliz vesayetindeki kral ve 1923 'ten beri yönetimde söz sahibi olan toprak ağalarına karşı 1946 yılında gerçekleştirilen sokak gösterilerinden biriyle başlamaktadır: “Dün geceki saldırı sadece İngilizlere karşı değil krala ve onun sömürgeci yandaşlarına da karşıydı. Bu, milli uyanışın yeni bir sayfası bana göre." (ez-Zeyyât, 1960, s. 6). İngiltere'nin 1947 yılında Hindistan'a bağımsızlık vermesine rağmen Süveyş Kanalından çekilmeye razı olmaması halkın hükümete karşı kırgınlığını artırmıştır (Cleveland, 2008, s. 336). Bir gurup gönüllünün kanal bölgesine harekâtı hükümet tarafından gerilla savaşı olarak değerlendirilmiş ve katılımcılar tutuklanmıştır. Romanda Leyla'nın ağabeyi Mahmud da bu harekâta katılıp tutuklananlar arasındadır.

\subsubsection{Devrimi}

Romanda tarihi akış içinde yer alan bir diğer konu 1952 Devrimidir. Söz konusu gerilla çatışmalarından birinde İngiliz tanklarının İsmailiye'de Mısır Polis Karakoluna saldırmasıyla 'Kara Cumartesi' olarak tarihe geçen olay gerçekleşmiş; ertesi günü (26 Ocak 1952'de) Kahire'de öfkeli halkın ayaklar altına aldığı asayiş, iktidar sorununu güçlendirdiği için 23 Temmuz 1952'de Hür Subaylar Harekâtı gerçekleşmiştir. Devrim olarak da adlandırılan olay diğer Mısır romanlarında olduğu gibi büyük sevinçle karşılanmış, bireyin ve toplumun hayat tasavvurunda olumlu etkisi olmuştur (Cleveland, 2008, s. 337).

\subsubsection{Port Sait Çıkartması}

Romanda Fransızların Port Sait'e asker çıartmasıyla (ez-Zeyyât, 1960, s. 418-431) ilgili betimlemeler çok güçlüdür. Olay, 26 Temmuz 1956'da Mısır Süveyş Kanalını millileştirdiğini ilan ettikten sonra Batılı başkentlerin bu karara askeri hareketle cevap vermesi neticesinde meydana gelir. İsrail Sina'ya saldırmış, İngiltere Kahire yakınlarındaki askeri hedefleri bombalarken Fransız paraşütçüleri 5 Kasım'da Port Sait'e inmiş, 6 Kasım'da BM'nin ateşkes kararıyla ilerleme durmuştur. Bu sahne Leyla'nın küllerinden doğduğu sahnedir.

\section{ROMANDA KADIN OLGUSU}

Maliye Bakanlığında memur Süleyman Efendi'nin 11 yaşındaki kızı Leyla, dinden ziyade geleneksel örüntülerin hâkim olduğu ailenin küçük çocuğudur. 17 yaşındaki ağabey Mahmut, geleneksel normları esnetmede erkek olmanın avantajını kullansa da aynı binada meskûn teyzenin onlarla yaşıt çocukları, aileler arası rekabeti besleyerek bu örüntüleri güçlendirir.

Leyla'nın karakter gelişiminin paydaşlarını toplumsal cinsiyet, gelenekler ve ailesiyle kurduğu ilişki oluşturmaktadır. Geleneğin intikalinde annenin başat rolünü komşu ve akrabalar desteklerken toplumsal cinsiyetin oluşumunda baba ön plana çıkar. Babanın anneyle kurduğu ilişki, Mısır toplumsalında aile yapılanmasının bir örneğini teşkil ederken bu örneklem Leyla'nın kişilik kompozisyonunun temel öğesidir. Yazarın söz konusu paydaşlarla oluşturduğu bütünün son parçası, Leyla'nın evdeki görünmezliğine bir erkeğin varlığında son verme çabasıdır. Söz konusu paydaşların Leylanın kişiliğindeki dağılımı aşağıdaki gibidir.

\subsection{Toplumsal Cinsiyet}

Her insanın doğuştan getirdiği özelliklere göre kadın ve erkek olarak belirlenen biyolojik cinsiyeti, ait olduğu kültürde ayrıştırılmış roller içine hapsedilmiştir. Kadına annelik ve ev işleri erkeğe de para kazanma sorumluluğu vermek gibi basitçe yapılan tasnifin çok daha derininde, kadını sosyal hayattan soyutlayarak sadece varlığını değil 
iradesini de yok sayma arzusu dini argümanlarla gücünü artırmaya çalışır. Çeşitli kültürlerde farklılaşan bu rollerin özellikle bebeklik ve çocukluğun ilk yıllarından itibaren toplum içinde öğrenildiği tezi, toplumsallaşma kuramı olarak adlandırılmaktadır (Pilcher, 2017, s. 110). XXI. Yüzyıl kadınların sosyal hayattaki cinsiyet ayrımını gen, hormon farkı gibi biyolojik temelli açıklamalardan ziyade toplumsallaşma kuramıyla açılamayı desteklemektedir.

Genel olarak Mısır romanı, ayrıştırılan kadınlık erkeklik rollerini bir tarafa bırakıp halkın birbirine kenetlenerek ulusal direnişe katıldığı örneklerle doluyken söz konusu romanda, millî mücadeleye uzak durarak statükoyu korumak isteyen bir aile örneği görülür. Süleyman Efendi'nin ulusal gündeme uzak oluşu muhtemelen kendi yağıyla kavrulmasına imkân veren gelirini kaybetme korkusudur.

Mahmut eylemlerde yaralandığında, Mısır romanlarındaki diğer aile tiplemelerinin tersine babası ona kızmış, Kanal bölgesine gönüllü olarak savaşmaya gittiğinde onu evlatlıktan reddetmiştir. Buna rağmen geleneklerin aşağı çektiği Mahmut'un vizyonu ulusal direnişten aldığı enerjiyle parlarken Leyla da ulusal direnişle kişisel hürrüyeti arasında kurduğu bağı güçlendirerek benliğini özgürlüğe kavuşturmaya çalışacaktır.

1946 Kasımında İsmailiye Meydanı'nda İngilizlere karşı gerçekleştirilen gösterilerde yaralanan Mahmut'la kendisini özdeşleştiren Leyla, düşmanla savaştığını hayal ederek, göstericiler gibi sağ elini havaya kaldırıp indirirken söylediği cümleler babasının otoritesinde sessizliğe bürünür:

“- Silah, silah! Silah istiyoruz!.. Aniden çivilenmiş gibi olduğu yerde kaldı. Kolları iki yana düştü. Leyla odaya giren babasına çarpmış, kelimeler dudaklarında ölmüştü." (ezZeyyât, 1960, s. 20).

Okulların hâkim ideolojiyi üretmedeki rolü, toplumsal cinsiyetin kadına çizdiği sınırları, sosyalleşme süreciyle öğretip iktidarın lehine kullanmasında da etkilidir. Mısır'da sokak eylemlerinin baş aktörlerinden olan öğrencilerin direnişe verdiği destek, okul idaresinin yaptırımlarıyla karşılık bulurken bireysel özgürlüğü ulusal özgürlükle özdeşleştiren kadınlar ve gençlerin eylemleri, Mısır romanının içeriği arasındadır.

Söz konusu romanda VEFD Hükümeti'nin Mısır'da İngiliz varlığının devam etmesi koşuluyla 1936 yılında imzaladığı kısmî bağımsızlık anlaşmasını 1951 yılında feshetmesi üzerine meydana gelen gösterilere, Hidiv İsmail Lisesi öğrencilerden de destek gelir. Çalan ders ziline rağmen sinıflara girmeyen, bahçede "Sömürgeciliğe son! Silah istiyoruz!" diye slogan atıp sokağa çıkmak için sabırsızlanan kalabalığa Müdire Hanım kürsüden seslenir:

"Kadının vazifesi anneliktir, yeri de evidir. Silah ve mücadele erkek işidir."

Mikrofonu kapan bir öğrenci titreyen sesiyle ona cevap verir:

“Sayın müdür 'kadının yeri evi, erkeğin yeri de savaş alanıdır' diyor. Ona şunu söylemek istiyorum: İngilizler 1919 yılında Mısırlıları katlederken kadın erkek diye ayırmadılar! Elinden özgürlügünü alırken de yiyeceklerini yağmalarken de bu ayrımı yapmamışardı.." (ez-Zeyyât, 1960, s. 57-58).

Leyla aynı okulda öğrenci teyze kızı Cemile'nin aksine, okul bahçesinden sokağa akın eden öğrenci seline kendini bırakıp babasının görmesine aldırmadan onlarla birlikte slogan atarken varlığının kâinatın varlığına karıştığını hisseder (ez-Zeyyât, 1960, s. 60). Ancak gösterilere katıldığı akşam babasından dayak yediğinde, çıkmak için çabaladığı kuyunun

SEFAD, 2021; (45): 21-34 
dibine bir kez daha düşecektir: "Asla annesine karşı gelemeyecek, babasına bă̆ıramayacak. Bütün hayatı boyunca gözyaşları sessizce akarken o, parmaklarının ucunda yürüyecek." (ez-Zeyyât, 1960, s. 63).

Leyla görünmezliği kabul ederek kendinden vaz geçtiği bu noktada, öğretilen kadınlık rolüne bürünerek başka bir bedende var olma arzusuna kapılır. Yazar büyük bir ustalıkla, aşkın bireysel benliğin inşasıyla var olacağını ispata giriştiği romanında Leyla'nın yıkılan kulelerini doğru temele inşa etme serüvenine okuyucuyu ortak eder.

\subsection{Gelenekler}

Sosyalleşmenin ilk adımı olan aile; yeni üyelerine kültürel öğelerin aktarımı için normları dayatıp onları beklendik kalıplara sokarken bireyin yaşadığı benlik ve toplum arasındaki ikilem, nadiren onun lehine sonuçlanır (ez-Zeyyât, 1960, s. 24). 11 yaşında hayatla arasına girecek bu engellerin henüz farkında olmayan Leyla, geleneklerin kendini mazur göstermek için sabırsızlıkla beklediği ergenliğe adım atııştır:

"Leyla, o gece Cemile'nin neden ona acıyarak baktığını, babasının neden gözyaşı döktü̈̆ünü anlamamıştı. Fakat zamanla reşit olunca kapısında babası, annesi ve ă̆abeyinin beklediği, stmırları geleneklerle çizilmiş bir hapishaneye girdiğini anladı. Hayat artık gardiyanlar için de tutuklular için de acı vericiydi. Gardiyan, toplumun oluşturduğu, değer verip koruduğu stnırları tutuklunun çiğnememesi için gece boyu uyuyamazken, tutuklu daha önce hissetmediği bir güçle mücadele ediyordu. Birden büyüyen, hayata karışma arzusu taşıyan bir güç... Kuşatılmış bedeninde; aptal, kör, sağır stnırların felç ettiği beyninde hissettiği bir güç..." (ez-Zeyyât, 1960, s. 31).

Reşit olduğunu öğrendiğinde babasının, ağabeyi Mahmut'un çenesinde sakallar çıktığı zamanki gibi sevinmesini bekleyen Leyla, tam tersi bir tavırla karşılaşmıştı:

"Büyüdü̆̆̈̈̈nü anlamalısın Leyla, tek başına dışarı çıkıp gezmeye gidemezsin. Evden okula, okuldan eve o kadar. Bakışların Mahmut'a çevirip ekledi: "Evde roman, dergi görmek istemiyorum, anladın mı? Okuyacaksan da (de) ya dışarıda oku ya da onları sakla. Evde bir kızın düşüncelerini zehirleyen şeylerin bulunmasını istemiyorum." (ez-Zeyyât, 1960, s. 31).

Baba, Mahmut'a arkadaşlarını eve getirmesini yasaklarken Leyla'ya teyze oğlu İsâm'ın yanında örtünmeden durmasına izin vermesi (ez-Zeyyât, 1960, s. 32) söz konusu tavırların din yerine geleneklerden beslendiğine kanıttır.
"Leyla hiçbir şey söylemedi. Kimse ondan bir şey söylemesini beklememişti zaten. Bundan sonra annesinin rolü başladı hayatında... Hiç bitmeyen rolü... Arkası dönükken bile, ayak seslerini duydŭ̆unda ne olduğunu bilmediği şeyler için azarlanmayı bekliyordu. Geleneklere aykırı ya da normlara göre doğru olmayan, hanımefendi bir kıza yakışmayan şeyler... İçten gelen bir kahkaha aykırıydı... Neden aykırı? Doğru, samimi bir söz aykırı! Neye aykırı? Geleneklere... O şey gelenek miydi?"
Oturdŭ̆unda neden bacak bacak üstüne atyorsun? Insanlar ne der sonra! Terbiyesiz?
-Insanlardan bıktım. Kimseyi görmek istemiyorum!
-Hayır, insanlarla görüşmelisin, neden saklanıyor derler sonra! Bir kusuru mu var yoksa?" (ez-Zeyyât, 1960, s. 32-33).

14 yaşında evde elini ayağını nereye koyacağını bilemeyen, zincirlere bağlanmış gibi ağır aksak yürüyen Leyla okulda hayat doludur. Ulusal direnişe katıldı̆̆ı için babasından 
dayak yediği günden beri hissettiği yalnızlık ve değersizlik, sevgi arayışı için itici güç olmuştur. Geleneğin biçimlendirdiği kadın erkek ilişkisi Leyla'nın hayatındaki dönüm noktalarından birisi olacaktır.

\subsection{Aşk ve Evlilik}

Mısır toplumsalında aşk ve evliliğe bakış bölgesel ve kültürel farklılığa göre değişmektedir. Batıyla temasından itibaren askeri ve bürokrat kesim arasında başlayan yeni yaşam tarzı, özellikle 1940'lı yıllarda, İngiltere'nin Mısır'ı savaş üssü haline getirmesiyle tabana yayılmış; sosyal hayatın bu görüntüsü, kadın ve evlilik teması etrafında kurgulanan romanlara da yansımıştır. Aşk ve evlilik konusuna bu romanlar çerçevesinde baktığımızda tek bir profil yerine söz konusu değişkenlere göre farklı formlar sergilendiği görülür.

İlk Mısır romanı Zeynep'te geleneklere kurban edilen aşk öyküsü 30'lu 40'lı yıllarda köy hayatını betimleyen romanlarda farklılaşmış, gençler ayıplansa da buna direnç göstermiştir. 1940'lı yıllarda Kahire'de orta halli bir ailenin hikâyesinin anlatıldığı "Açık Kapı" romanında aşka ve aileye bakışı şekillendiren geleneksel normlar, yeni nesil arasında sorgulanmaya başlamış ancak bu olgu henüz kırılma noktasına ulaşmamıştır. Gençlerin temasa geçebildikleri yakın çevreleriyle yaşadıkları duygusal ilişki ya aile engeline ya da normların dayattığı eğlenilecek-evlenilecek kız ayrımına takılmıştır:

\footnotetext{
"Sen de annen gibisin Adile! Onun gibi düşünüyorsun. Annen sevmeden evlendi çünkü başka türlü yapamazdl. Tercih etme gücü yoktu, birini tercih etseydi de onunla evlenemezdi. Annelerimiz önce babalarını mülkiyetindeydi sonra mülkiyetleri kocalarına geçti. Fakat bizim bahanemiz olamaz, okuduk, öğrendik ve her şeyi anladık. Hayatımıza yön vermek zorundayız." (ez-Zeyyât, 1960, s. 92).

"Biz daha kötü durumdayız... En azından annelerimizin durumu netti fakat biz arada kaldık. Mülk müyüz, değil miyiz bilmiyoruz. Aşk helal mi haram mı? Ailemiz haram derken devlet radyosu sabahtan akşama kadar aşk şarkıları çalıyor. Kitaplar: 'Kızlar özgürdür.' diyor. Bir kız buna inanacak olsa başı ailesiyle belaya girip işitmediği azar kalmıyor! Biz daha zavallı değil miyiz?" (ez-Zeyyât, 1960, s. 94).
}

Evliliğe dair aşağıdaki cümleler başlangıçta iki kişi üzerine kurulan ancak çocuklarla alanı genişleyen ailede babanın konumuna dair önemli bir örnektir:

\footnotetext{
"Sonra suskun, ifadesiz yüzüyle babası gelir, bunu evdeki herkese bulaştırırdı. Anne parmak ucunda yürür, her şeyin olması gerektiği gibi hazır olduğundan emin olmak için endişeli gözlerle etrafını kolaçan ederdi. Azarlanmayı gerektirecek bir suç işlememek için gayret sarf ettiği halde baba sofrada yine usulca anneyi azarlardi.

"Mahmut toplumda kutsanmış geleneklerle dalga geçmeye başlayınca Leyla'nın gözü parlar, annesinin dudakları titreyip baba öfkelenmeye başlayınca ustalıkla konuyu değiştirirdi." (ez-Zeyyât, 1960, s. 36).
}

Leyla kuzeni İsâm'ı neredeyse her gün gördüğü halde, eylemlere katıldığı için babasından dayak yediği gece, teselli etmek için odasına geldiğinde fark etmesine şaşırmıştır. Değer görmeden büyüdügü için güven duygusunu yitiren Leyla'nın bir erkeğin varlığında değer bulma arayışı kendine güveneceği güne kadar devam edecektir.

Duygularıyla gelenekler arasında yaşadığı gelgitlerinde, her kabullenişi, içinde filizlenen özgürlükle sarsılırken, İsâm ona "Sen benim mülkümsün" (ez-Zeyyât, 1960, s. 168) dediğinde, "Üniversiteye gitmene ne gerek var, her kızın sonu evlilik." sözüyle eğitimine karşı çıktığında Leyla bu duyguyla yüzleşecektir. 
Kadınları evlenilecek ve eğlenilecek kadınlar olarak kategorileyen İsâm, bu anlamda evlenmek istediği Leyla'yla temasa geçemeyeceğinden evdeki hizmetçiyle ilişkiye girer. Öğrendiğinde büyük bir hayal kırıklığı yaşayan Leyla İsâm’la ilişkisini bitirerek kendini tamamen geleneklere teslim eder. Öyle ki ağabey Mahmut'un kanal bölgesinde savaşırken tanıştığı Hüseyin, benliğini bulması için ona yardım etmek istese de içine düştüğü kuyuda kalmaya kararlıdır. Hüseyin, onu bir ömür bekleyeceğini söyleyerek eğitim bursuyla yurt dışına gitmiş, Leyla felsefe eğitimine başlamıştır.

Üniversitede Leyla duygusal çıkışlarıyla geleneklere olan inancını sarsan Sînâ yerine Adile'ye yakın durarak ondan güç almaya çalışır:

\begin{abstract}
"Adile'yle birlikteyken hayat ona kolay, basit, endişe ve kedersiz gözüküyordu. Matematik problemi gibi kurall ve sonucu kesin. Önemli olan insanın dikkatlice, kurnazca, tutkuyla ve ani hamle yapmadan bu kurallara uymasıydr. Aksi takdirde yanılıp rakamlar karıştırabilir, her şey birbirine girip çaresiz bir şaşkınlı̆̆a düşebilirdi. Adile herkesin bildiği, sınırları belli bu kuralları iyi biliyordu. Bunları bilen doğru ile yanlışı ayırt edebilir, huzurlu ve istikrarl, saygın ve doğruluğundan emin olduğu yolda yürüyebilirdi. Sadece kendisi için doğru olan değil herkes_için doğru olan yolda..." (ez-Zeyyât, 1960, s. 265).
\end{abstract}

Üniversitede Leyla'yı yakın takibe alan, sahiplenerek terbiye etmeye çalışan hocası Dr. Remzi'nin bu tavırlarının ardında onunla evlenmek isteği olduğu çok geçmeden anlaşılır. Hayat felsefesinin evlilik tahayyülünü de değiştirdiği Leyla, Dr. Remzi'nin kendisine açılmadan onu babasından istemesini ve babasıyla_aralarında anlaşmalarını kabul eder. Geleneklerin bunu gerektirdiğine inanarak kendisini ikna etmeye çalışsa da ağabeyiyle Sina'nın kıskançlık ve şüpheden uzak, sakin ve istikrarlı büyüyen aşkları ve ailelerinin karşı çıkmasına rağmen evlenmeleri bu inancını sarsmaya başlayacaktır.

İsâm gibi Dr. Remzi de Leylayı evleneceği kadın olarak seçerken eğlenilecek kadınlarla ilişkiyi mazur görmektedir. Şahit olduğu birkaç olayla Leyla'nın kalbinde fısıldamaya başlayan tereddüt Hüseyin'den aldığı mektupla kulaklarında çınlamaya başlar:

"Seni seviyorum ve senden beni sevmeni istiyorum fakat varlı̆̆ın ne benim ne de başkasının varlığında yok etmeni istemiyorum. Kendine, hayata, bana, insana olan güvenini kaybetmeni istemiyorum. Kendin olman, başkasindan değil kendinden güç almanı istiyorum. Isste o zaman kimse seni kıramaz, ne ben, ne de başkası. Isste o zaman sana tokat atana tokat atıp yoluna devam edebilirsin. İşte o zaman varlı̆̆ını başkasının varlı̆̆ıyla birleştirebilir, ışıldayıp çoğalır, yenilenirsin. İşte o zaman mutlu olabilirsin. Mutsuzsun sevgilim, ne kadar çabalasan bunu benden gizleyemezsin.

Mutsuzsun çünkü içindeki yaşam arzusu ölmedi, tam tersi yaşıyor ve gün yüzüne çıkmaya çalışıyor.

Hayata atıl sevgilim, varlığını başkasının milyonlarca başkasının varlığıyla, bu güzel topraklarla, vatanımızla, bu güzel halkla, halkımızla birleştir. Bana ve kendine olan sevgiden daha büyük bir sevgi bulacaksın, kimsenin senden alamayacă̆ı bir sevgi. Daima kulaklarında yankulanan, kalbine yansıyan, insanı büyüten ve dirilten bir sevgi, vatan sevgisi..." (ez-Zeyyât, 1960, s. 273-274).

Leyla, 1956 yılında Abdunnâsır'ın Süveyş Kanalı'nı millileştirdiğini açıkladığı konuşmasından sonra Mahmut'a yazdığı mektupta ona şöyle seslenecektir: 


\begin{abstract}
“Çok uzun zamandan beri kendimi Abdunnâsır'ın konuşmasını dinlerken hissettiğim gibi hissetmemiştim. Güçlü olduğumu ve her şeyi yapabileceğimi hissettim, her şeyi... Beni anlıyor musun? Unuttuğum güç ve aidiyet yeniden bana geri döndü. Artık yalnız değilim." (ez-Zeyyât, 1960, s. 400).
\end{abstract}

Remzi evlilik hazırlıkları için Leyla'nın atanmasını beklemektedir. Tayininin Kahire'ye yapılması için uğraşırken Leyla'nın ilk tercih olarak Port Sait'i yazdığından habersizdir. Hata sandığı atamayı yakın dostlarını araya koyarak birkaç ay içinde düzeltmeyi düşünmüştür ancak Fransa'nın bölgeye yaptığı çıkartma Leyla'nın ruhunda başlayan değişimi hızlandırır. Bombardıman günü limanda yaşananlar Leyla'nın vatan sevgisinde dirilmesini sağlamış, Dr. Remzi'den ayrılarak Hüseyin'le birlikteliğe hazırlanmıştır.

\title{
SONUÇ
}

Toplumsal hayatın aynası olan romanlar, ait olduğu ulusun tarihi ve sosyal zeminde geçirdiği sürecini takip etmek, olgularla ilgili araştırmayı vesikalardan ziyade bireyler arasında sürdürmek için paha biçilmez kaynak olmuştur. Özellikle Ortadoğu ülkeleri için dayatılan hükümlerin romanlar aracılığıyla sağlamasını yapmak, toplumdan beslenen yazarların kurguladığg hikâyelerde bölge insanını arayıp bulmak hem keyifli hem sağlıklı bir yolculuktur.

Ortadoğu ülkelerinde demokrasi sorunuyla ilgili şimdiye kadar kurulan cümleler, Arap Baharıyla sorgulanmaya başlarken söz konusu bölgede yer alan devletleri münferit olarak kültürel ve siyasi zeminde değerlendirme zarureti_unutulmamalıdır. Buradan hareketle Batıyla teması en erken gerçekleşen Mısır'da ülke ve bireyin özgürlüğüne dair iddia edilenler edebî literatürle kıyaslandığında oldukça farklı olduğu görülecektir Yine yirminci asrın ilk çeyreğinde başlayan kadın hareketlerinin ülkenin kültürel ve dinî zeminiyle birlikte otoriter rejimlerin engeline takıldığı ve şarkiyat araştırmalarının söz konusu bölge kadınını hapsettiği alanın yerel zeminin kadını hapsettiği alandan daha dar olduğu konuya hâkim olanların malumudur.

Mısır'da ulusal direnişle paralel seyreden kadın hareketleri laik ya da dinî düşünce sistemlerinin ortaklaşa kabul ettiği bir konudur. 1924 yılında VEFD Partisi_kadın komitesi lideri Hüdâ eş-Şârâvî'nin 1924 yılında kurduğu Mısır Feminist Birliği hareketin çıkış noktası olurken, Afgânî, Muhammed Abduh çizgisinde seyreden dinî çözüm önerileri, Lebîbe Ahmed ve Zeynep el-Gazali'nin söylemlerinde 'İslami Feminizm' kisvesine bürünmüştür. Farklı zeminden beslenen bu aktivistlerin ortak noktası ülkenin özgürlügüule kadının özgürlügünü bir arada tasarlamalarıdır.

Latîfe ez-Zeyyât'ın 1960 yılında okuyucuyla buluşan Açık Kapı (el-Bâbu'l-Meftûh) adlı romanı söz konusu tasarımın hikâyesidir. Geleneklerle, özgürlüğe kanat çırpan ruhu arasına sıkışan Leylâ ülkenin özgürlük yolunda elde ettiği her kazanımla güç toplayıp normlara meydan okumaya çalışırken her yenilgiyle kendini özdeşleştirip geleneklere teslim olmaktadır. Gücünü geleneklerden alan normlar kültürün devamı için nesilden nesile aktarılırken bireylerin benlik algısına göre esneyip değişime maruz kalır. Değişimin ölçüsü bireyin kendine olan inancı ve geleneğe olan direncidir. Söz konusu roman gündelik hayatın sıradan eylemleriyle normları esneterek kimliğini inşa eden kadının hikâyesini anlatırken benlik tasarımı, aşk, evlilik gibi toplumsal konuların söz konusu zamanda ait olduğu tabakadaki görünümü hakkında bilgi vermektedir. 
Mısır'da, 1919'da İngiltere'ye karşı özgürlük mücadelesiyle başlayan kadının görünürlüğü, sokak eylemleriyle güçlenip en korunaklı evlere kadar sızmış ve bu tarihten itibaren yazılan her roman belli ölçüde değişimin nabzını tutmuştur. Kadının ve vatanın mahremiyetini korumakla başlayıp özgürleştirmekle son bulurken bu ikilinin birbiriyle etkileşimi, söz konusu romanda ana temayı oluşturmaktadır. Toplumsal cinsiyetin yumuşayabileceği tek alan olan ulusal direnişle başlayan kadın hareketi, Ortadoğu ülkelerinde ancak otoriter rejimlerin demokrasiye geçişiyle mümkün olacaktır.

\section{SUMMARY}

While the concepts of "woman" and "homeland" play the lead roles in the making of national history through the notion of "chastity", the women's search of freedom -which feeds on national resistance in Egypt- evolves into an individual attitude over the course of time. We can see this quite clearly in al-Zayyât's novel the Open Door, which depicts the events occurring in the political history of Egypt in a period of ten years' time starting right before the coup in 1952. The novel discusses woman's visibility in society -namely arising from national resistance, her struggle with obstacles such as traditions and norms hindering her freedom, and her search of identity.

The Open Door, which met its readers in 1960, is the story of the previously mentioned plan. Squeezed between traditions and her spirit's spreading wings to freedom, Layla tries to gain strength to challenge norms with country's every achievement towards freedom, yet identifies herself with each defeat and surrenders to traditions. As the novel describes a woman's story of bending daily life's mundane acts and norms to build her identity, it also informs us on how social issues like self-representation, love, and marriage were received in the class rank she belonged to in those times. Since Egyptian women's existence in social sphere commenced with national resistance and their visibility in the country increased with the reforms following coup in 1952, the deliberately used political setting of the novel is a characteristic of Egyptian novels.

Connecting daily life to historical events, perceiving political success as a means to celebrate, clinching unity and solidarity around national resistance, and creating characters linked to politics are the essentials of Egyptian novels.

In this novel, political stream of the country that starts in 1946, continues until 1957 and Layla's soul is deeply affected with each gain and loss. Layla, the 11-year-old daughter of Muhammad Effendi Sulayman who is a civil servant in the Ministry of Finance, is the youngest of the family that is dominated by traditional culture rather than religion. Although her 17-year-old brother Mahmud takes advantage of being a male to bend traditional norms, their aunt's peer children living in the same building increase the families' rivalry and make those norms stronger.

The development of Layla's character is actualized by social gender, traditions and her relationship with her family. While neighbours and relatives support mother's main role for the transition of tradition, father becomes prominent in establishing social gender. As the relationship the father has with the mother represents an example of family structure in the Egyptian Society, this sample is the main component of Layla's personal composition. Also, the author formed with the components mentioned before is Layla's attempts to overcome her invisibility at home through a man's existence. The distribution of those components in Layla's personality is as below: 
We can see the role of family in constructing the dominant ideology, the use of limits set for women by social gender and taught through a socialization process in favour of the ruling power. While the support that students show is faced with school management's reprimands, the role that the youth -also including women who identify individual freedom with national freedom- have in activism is frequently observed in Egyptian novels. Womanman relationship that is shaped by tradition is one of the turning points in Layla's life.

Makale Bilgileri

Etik Kurul Kararı:

Katılımo Rizası:

Mali Destek:

Çıkar Çatışması:

Telif Hakları:

Article Information

Ethics Committee Approval:

Informed Consent:

Financial Support:

Conflict of Interest:

Copyrights:
Etik Kurul Kararından muaftır.

Katılımc1 Yok

Çalışma için herhangi bir kurum ve projeden mali destek alınmamıştır.

Çalışmada kişiler ve kurumlar arası çıkar çatışması bulunmamaktadır.

Telif hakkına sebep olacak bir materyal kullanılmamıştır.

Exempt from the Ethics Committee Decision.

No participant

No financial support from any institution or project.

No conflict of interest.

No material subject to copyright is included. 


\section{KAYNAKÇA}

Berâzî, H. (2016). el-Hareketu'n-nisevitteti'l-mısriyye: beyne'l-mevrûsi's-segâfiyyi ve'nneşâti's-siyasiy. İnsaniyât, 2016/74, 11-28.

Bora, A. (2010). Hatırlananlar ve unutulanlar: İslam coğrafyasında modernleşme ve kadın harketleri. Bilig: Türk Dünyası Sosyal Bilimler Dergisi, 2010/53, 51-66.

Cleveland, W. (2008). Modern Ortadoğu Tarihi. İstanbul: Agora Kitaplığı.

Demirtaş, E. (2014). Ortadoğu'da Devlet ve İktidar. İstanbul: Metis Yayıncılık.

Kandiyoti, D. (1997). Cariyeler, Bacılar, Yurttaşlar: Kimlikler ve Toplumsal Dönüşümler. İstanbul: Metis Yayınları

Kemâl, H. (2016). Lemehâtün min Metâlibi'l- Hareketi'l Niseviyye el-Mısriyye abre Târiyhiha. Mısır: Müessesetu'1-Mer'e ve'z-Zâkire.

Lewis, P. (2007). Zainab al-Ghazali: pioneer of Islamist feminism. Michigan Journal of History, 2007/2, 1-47.

Pilcher, J. (2017). Cinsiyet ve cinsiyet eşitsizlikleri üzerine açıklamalar. A. Giddens (Ed.), Sosyoloji Başlangıç Okumaları içinde, (s. 109-119). İstanbul: Say Yayınları.

Tolan, B. (1996). Toplum Bilimlerine Giriş. Ankara: Adam Yayıncllık.

Zeyyât, L. (1960). el-Bâbu'l-Meftuh. Kahire: el-Karma. 